\title{
Ultrastructural Study of Poxvirus Causing Myxomatosis in Rabbits, in São Paulo and Santa Catarina, Brazil
}

\author{
Estudio Ultraestructural del Poxvirus Causal de Mixomatosis en Conejos, \\ en São Paulo y Santa Catarina, Brasil
}

"Catroxo, M. H. B.; "Bersano, J. G.; ${ }^{*}$ Martins, A. M. C. P. F.; ${ }^{* *}$ Petrella, S.; ${ }^{*}$ Portugal, M. A. S. C. \& ${ }^{* * *}$ Souza, O. S.

CATroXo, M. H. B.; BerSAnO, J. G.; MARTINS, A. M. C. P. F.; PETRElla, S.; PORTUGAL, M. A. S. C. \& SOUZA, O. S. Ultrastructural study of poxvirus causing myxomatosis in rabbits, in São Paulo, and Santa Catarina, Brazil. Int. J. Morphol., 27(2):543$552,2009$.

SUMMARY: The myxomatosis is a contagious worldwide disease caused by poxvirus which infects domestic and wild rabbits. In the present study we present two distinct outbreaks of myxomatosis when raising rabbits, one for commercial purpose of production of meat and skins and, another one for the commercialization of ornamental rabbits. The observed signs were ocular, auricular, nasal, testis lesions and many times scattered throughout the body of the animals. The lesions were characterized by formation of nodules that by palpation disclosed gummy or gelatinous aspect. At the transmission electron microscopy, all the skin and crust samples were analyzed by negative staining technique. A great number of particles with morphology similar to the poxvirus, some enveloped in a brick-shaped and irregular disposition of tubules on the external membrane, measuring $300 \times 240 \mathrm{~nm}$ on the average were visualized. Ultrathin sections revealed the presence of intracytoplasmic inclusion bodies surrounded by membrane containing oval particles, measuring $270 \mathrm{x} 130 \mathrm{~nm}$, containing nucleus or an internal biconcave (dumbbell-shaped) core. Immature particles (empty), surrounded by membrane were also observed. In addition, intracytoplasmic electron dense inclusion bodies containing viral particles budding of dense amorphous material and intranuclear fibrillar or "digital" inclusions showing a regular striation and arranged in groups were found in the middle of granular material. The nuclei were deformed with densely condensed chromatin forming amorphous and electron dense inclusion bodies. In the immunocytochemistry technique, the antigen-antibody reaction was strongly marked by the particles of colloidal gold, emphasizing the viral particles. The techniques used in this study were important in the diagnosis of the affected animals.

KEY WORDS: Myxomatosis; Poxvirus; Rabbits; Transmission electron microscopy.

\section{INTRODUCTION}

Myxomatosis is a severely debilitating infectiouscontagious disease that affects the wild and domestic rabbits (Fenner et al., 1992). Etiological agent was first isolated from a colony of laboratory rabbits, in Uruguay, 1898 and characterized as a poxvirus only in1927. In natural hosts of the leporid species, Sylvilagus brasiliensis in South America and Sylvilagus bachmani in California, the viral strains produce in adult animals benign fibroma and generalized disease in young animals. In the European rabbits, two forms of the disease have been identified, the nodular classic and the amyxomatous or respiratory form (Fenner \& Hatclife, 1965).

In nodular myxomatosis, after incubation period of 2-10 days, the first sign is the appearance of a nodule, in general, in the ocular region which increases in size, becomes protuberant and ulcerates evolving to blepharoconjunctivitis and mucoid subcutaneous tumor formation in the face and ear, originating deformities that confer to the animal a leonine aspect. Additionally, small nodule tumors appear in extremities and genital organs (Fenner et al.) and orchiepididymitis causing infertility (Ferreira \& Ferreira, 1990; Fenner \& Fantini, 1994; Fountain et al., 1997). The disease may evolve, between 48 hours and 12 days, to paralysis and death (Ferreira \& Ferreira), being the estimated death rate ranging from 20 to $100 \%$ depending on the viral strain. In the recovery process, the lesions gradually heal (Arthur \& Louzis, 1988). There are several vectors of transmission in the nodular form (Beer, 1999). In England,

* Laboratory of Electron Microscopy, Research and Development Center in Animal Health, Institute Biological of São Paulo, SP, Brazil.

*** Medical Biology Division, Adolfo Lutz Institute, São Paulo, SP, Brazil.

${ }^{* * * *}$ Veterinary Doctor, Santa Catarina, SC, Brazil. 
the rabbit's flea is the mayor transmitting agent, in some areas of Europe, the mosquitoes (Fenner \& Fantini), in Mexico, the mosquitoes of the Ceratopogonidae and Anthomyiidae family (Luna, 2000), in Brazil, flies, fleas and mosquitoes Aedes aegypti, Anopheles and Culex (Ferreira $\&$ Ferreira). Airborne transmission is also reported in the literature, as well as by direct contact among enclosed rabbitries (Farsang et al., 2003).

In the amyxomatous form, the main symptom is in the respiratory tract which may evolve to pneumonia or bronchopneumonia besides the presence of small nodules in the skin (Fenner et al.; Marlier et al., 2000). An outbreak of atypical myxomatosis characterized for respiratory symptoms of the superior tracheal tract associated to the conjunctivitis and high mortality was reported in the Hungry (Farsang et al.). The transmission of this form of disease occurs by direct contact among enclosed rabbitries. It is important to emphasize that this type of transmission was also detected in wild rabbits (OIE, 2008). As well, in mountain hares a contagious mucocutaneous dermatitis caused by a poxvirus was found (Saari et al., 2005).

The myxomatosis was reported in various parts of the world, as Mexico, Australia, Spain, France and England (Shepherd et al., 1978; Ross et al., 1989; Ghram et al., 1996; Gelfi et al., 1999; Luna; Calvete et al., 2002; Merchant et al., 2003). In Brazil, myxomatosis occurs periodically and, in the last 20 years, only two outbreaks had been reported, both in Rio de Janeiro state, in rabbitries of small domestic producers, with high mortality (Barbosa et al., 1996; Bruno et al., 2004).

The poxvirus, member of the Poxviridae family, Leporipoxvirus genus is among the largest and most complex of all animal viruses. They do not possess nucleocapsid and the external membrane contains a central zone dumbbellshaped and two lateral bodies of unknown nature. The irregular disposition of the tubules on the external lipoproteic bilayer confers it a textured characteristic appearance. Its replication occurs in the cytoplasm and the particles released by rupture of the cell acquired an envelope form (Doane \& Anderson, 1987; Fenner et al.; Fenner, 1996, 2000; Diven, 2001).

The genome of myxoma virus, DNA of double strand of $162 \mathrm{Kbp}$ (Cameron et al., 1999) has a central region with structural and enzymatic genes highly conserved, essential to the maintenance of the functions of viruses (Upton et al., 1990). The capsid is composed for 17 different proteins (Zachertowska et al., 2006), being that the (MV) M-T5 gene codifies an important protein in the viral replication (Johnston et al., 2005) and the M141 R gene a necessary protein to the development of a lethal infection in vivo (Cameron et al., 2005).

The transmission electron microscopy has been widely used for many authors to detect typical particles of poxvirus (Tektoff et al., 1971; Purcell \& Clarke, 1972; Yuill, 1972; Marcato \& Simoni, 1977; Barbosa et al.; Luna; Farsang et al.; Saari et al.; Ganière et al., 2008), being one of the techniques more recommended by the OIE for the accomplishment of the laboratorial diagnosis of the virus, in suspension of skin lesion.

Considering effectiveness of this technique, our proposal was to detect the etiological agent in skin lesions of rabbits regarding the two outbreaks.

\section{MATERIAL AND METHOD}

Description of the outbreaks. The first outbreak was detected in 1978, in São Paulo, in the city of Itapecirica da Serra in a rabittrie with 340 rabbits of Flandres Giant New Zealand White strain, whose production was for consume and the animal skin for industry. Among those, 26 adult animals presented the disease with conjunctivitis and rhinitis with a sanguineous mucous fluid and when dry it formed adherent crusts to nasal orifices (Fig. 1). The ocular status evolved to panophthalmitis with accentuated palpebral edema and by palpation, the periorbital region revealed a gelatinous texture. Some animals presented lesions on the paws and ear extremities with became edemaciated (Fig. 2). The testis of four male reproductive rabbits, were swollen and with a gelatinous texture (Fig. 3). Eleven out of the 26 sick rabbits went to death.

The second outbreak, in 2002, occurred in Santa Catarina, in the city of Sangão (Jaguariúna), in a rabbitrie with approximately 150 ornamental rabbits. Animals presented nystagmus, motor incoordination followed by anorexia, depression, opaque pelage, subcutaneous edema, conjunctivitis, otitis, rhinitis, face malformation, caquexy and death. Most of the young animals (0 to 60 days) went to death without showing signs of the disease. Some adult animals recovery but anorexia and cutaneous folds in the neck (chin) area remained. The mortality rate initially low, increased over the months, and only 20 animals remained but with contagious symptoms.

Electron microscopy techniques. Fragments of skin lesions and dry crusts were collected and sent to the Electron Microscopy Laboratory of the Biologic Institute, São Paulo, 


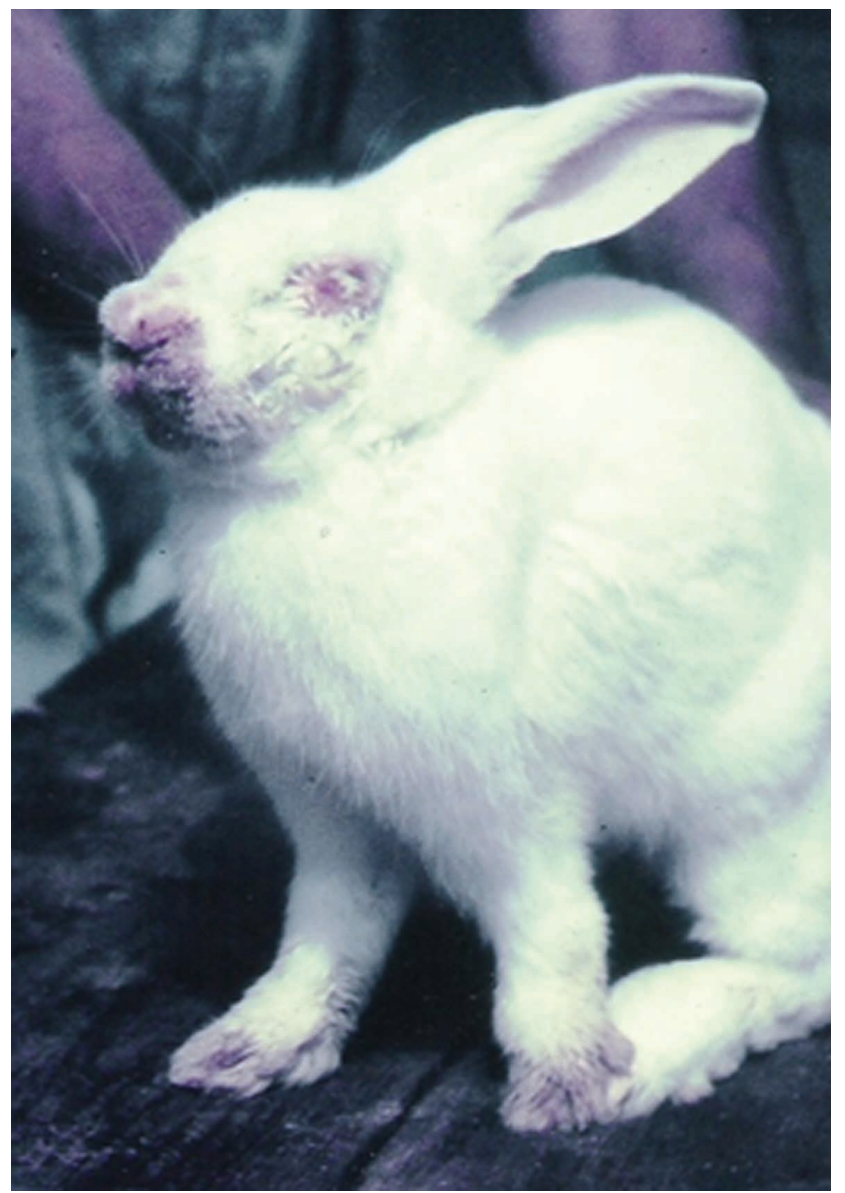

Fig.1. Animal showing conjunctivitis and rhinitis and abundant mucosanguineous fluid and crust formations.

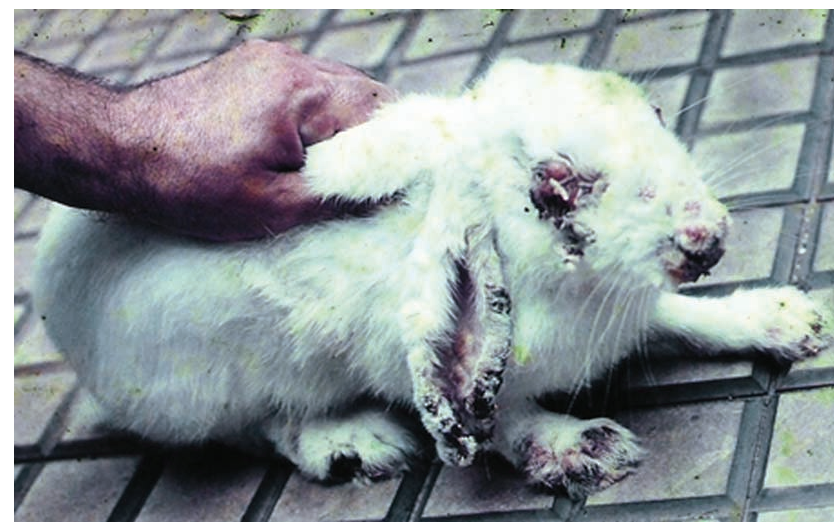

Fig.2. Animal with panophthalmia and rhinitis. Observe the ear markedly edemaciated with lesions along the border, edema in paws and lesion in the fingers

Brazil. They were processed for transmission electron microscopy using negative staining (rapid preparation), resin embedding and immunocytochemistry techniques.

Negative staining technique (rapid preparation). The negative staining process was performed according to the methodology described by Brenner \& Horne (1959), Hayat \& Miller (1990) and Madeley (1997). In this technique the clinical samples were suspended in phosphate buffer $0.1 \mathrm{M}$ and $\mathrm{pH} 7.0$, placed in contact with metallic copper grids with carbon stabilized supporting film of $0.5 \%$ collodium in amyl acetate. Next, the grids were drained with filter paper and negatively stained at $2 \%$ ammonium molybdate, $\mathrm{pH}$ 5.0.

Resin embedding technique. Fragments of skin lesions and dry crusts were fixed in $2.5 \%$ glutaraldehyde in $0.1 \mathrm{M}, \mathrm{pH} 7.0$ phosphate buffer and pos-fixed in $1 \%$ osmium tetroxide in the same buffer. After dehydration in cetonic series, the fragments were embedded in Spurr resin (GonzálezSantander, 1969; Luft, 1961). Ultrathin sections were cut on the LKB ultratome and mounted on copper grids. The sections were contrasted with uranyl acetate-lead citrate (Watson, 1958; Reinolds, 1963).

Immnunocitochemistry technique. At the immunolabeling technique with colloidal gold particles for negative staining, the copper grids were placed in contact with viral suspension and, after removing excess with filter paper, the same were

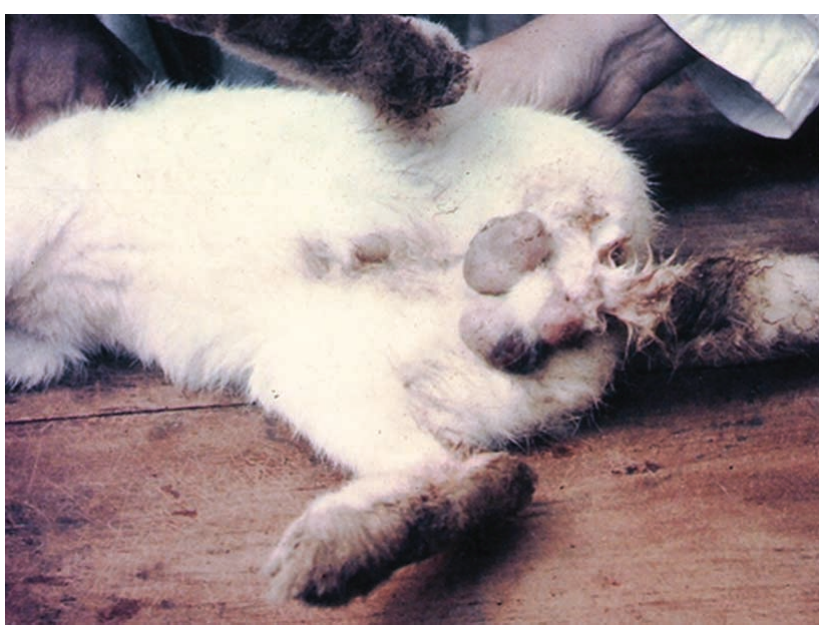

Fig. 3. Testis impairment where we can observe increase in volume.

put on specific primary antibody drops. After successive washings in PBS drops, the grids were incubated in protein A drops in association with $10 \mathrm{~nm}$ gold particles (secondary antibody). Grids were then contrasted at $2 \%$ ammonium molybdate, pH 5.0 (Knutton, 1995). Observations were made in a Philips EM 208 electron microscope, at $80 \mathrm{kV}$.

\section{RESULTS}

Negative staining technique (rapid preparation). A great number of particles with morphology similar to the poxvirus, 
some enveloped (Fig. 5, arrow) in a brick-shaped and irregular disposition of tubules on the external membrane (Fig. 4, arrow), measuring $280 \times 230 \mathrm{~nm}$ on the average were visualized in all the samples of the fragments of skin lesions and dry crusts negatively stained at $2 \%$ ammonium molybdate.

Resin embedding technique. Ultrathin sections of the fragments of skin and crusts, positively stained by combination of uranyl acetate and lead citrate, revealed the presence of intracytoplasmic inclusion bodies (Fig. 6), surrounded by membrane and containing oval viral particles,

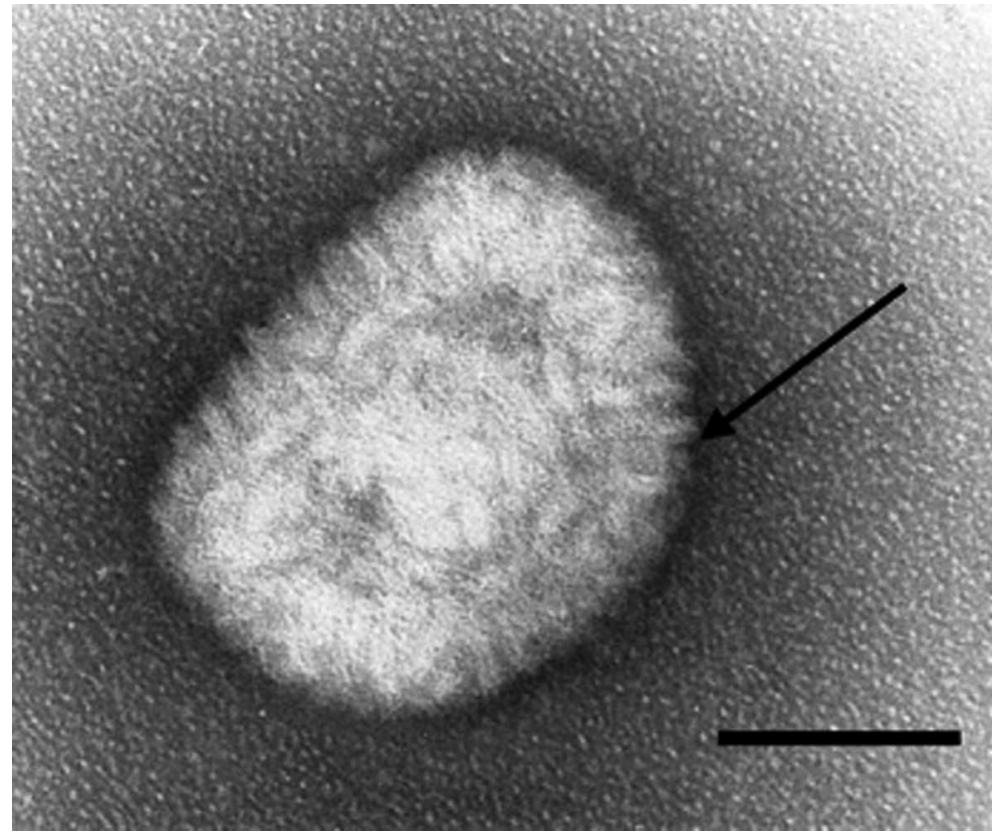

Fig. 4. Negatively stained poxvirus showing irregular disposition of tubules on the external membrane (arrow). Bar $=100 \mathrm{~nm}$. measuring $270 \times 130 \mathrm{~nm}$, with a nucleus or internal biconcave (dumbbell-shaped) core (Fig. 6, big arrow). Immature particles (empty), surrounded by membrane were also observed (Fig. 6, minor arrow). Intracytoplasmic electron dense inclusion bodies (Fig.7), containing viral particles (Fig. 7, lower arrow) budding of dense amorphous material (Fig.7, big arrow) were also observed. Intranuclear fibrillar or "digital" inclusions (Fig. 8, arrow), showing a regular striation and arranged in groups (Fig. 9, arrow) were found in the middle of granular material.

There were still a large number of intracytoplasmic vacuoles, surrounded by membranes, measuring between 480 and 1150 $\mathrm{nm}$ in diameter (Fig. 10). Some vacuoles contained granular material in its interior or on the external surface (Fig. 10, big arrow) and electron dense fibrils could be seen around some of the vacuoles (Fig. 10, minor arrow).

The nuclei were deformed with densely condensed chromatin forming amorphous and electron dense inclusions bodies (Fig.11, arrow).

Immnunocytochemistry technique. In the immunocyto-chemistry technique, the antigenantibody reaction was marked by the particles of colloidal gold, strongly enhanced the viral particles (Fig. 12, arrow).

Fig. 5. Negatively stained poxvirus showing enveloped particle (arrow). Bar $=130$ nm.

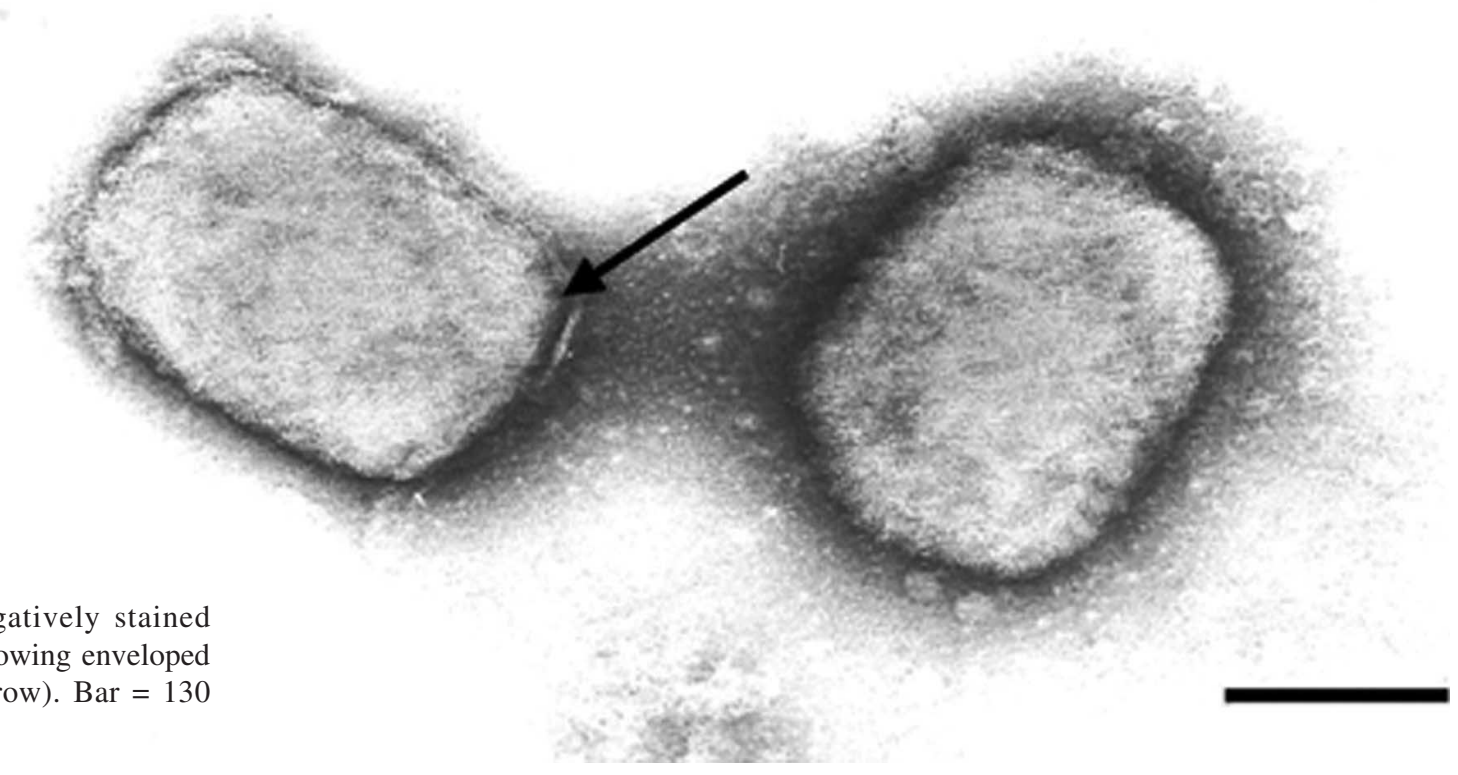




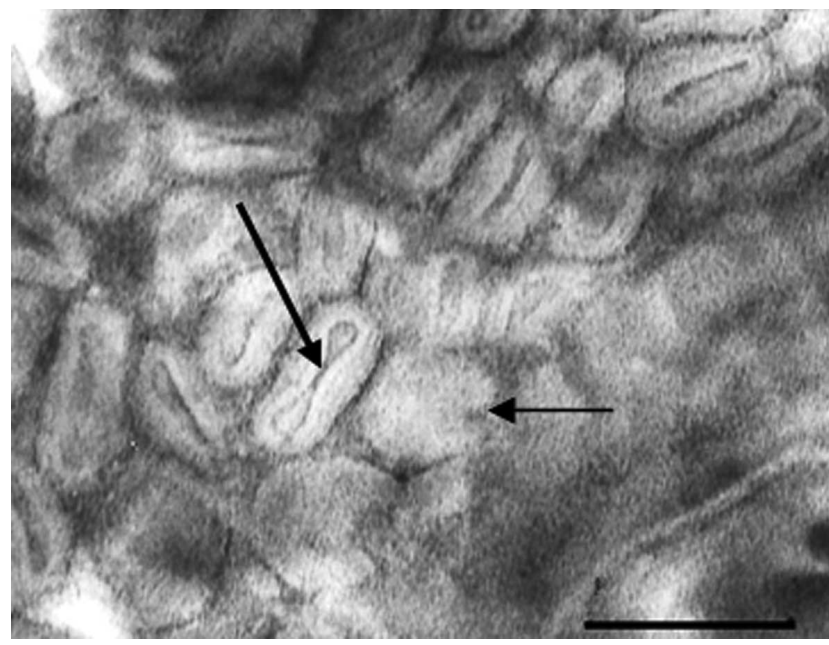

Fig. 6. Ultrathin section of the fragments of skin. Intracytoplasmic inclusion bodies containing oval viral particles with a nucleus or internal biconcave (dumbbell-shaped) core (big arrow). Immature particles (empty), surrounded by membrane (minor arrow). Bar $=200 \mathrm{~nm}$.

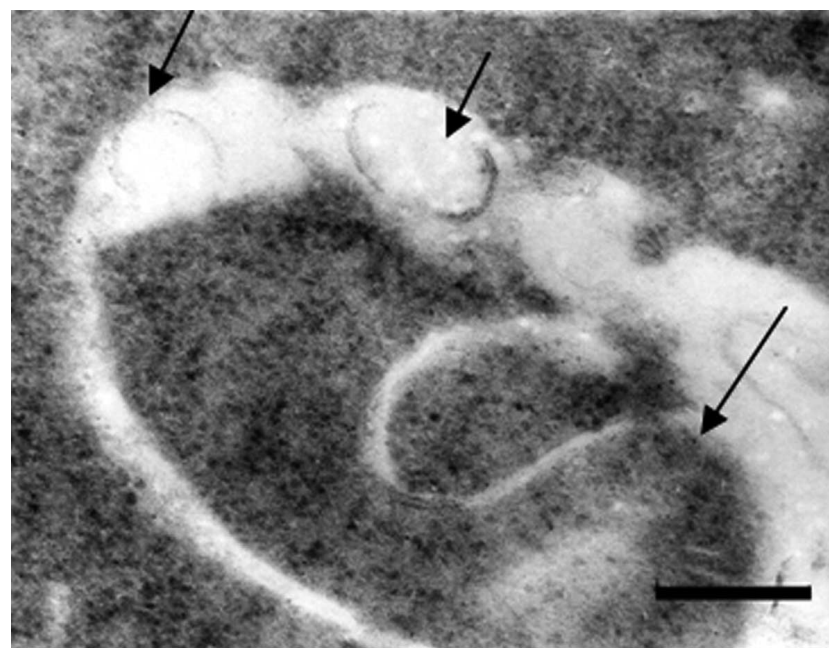

Fig. 7. Ultrathin section of the fragments of skin. Intracytoplasmic electron dense inclusion bodies, containing viral particles (lower arrow) budding of dense amorphous material (big arrow). Bar $=320 \mathrm{~nm}$.

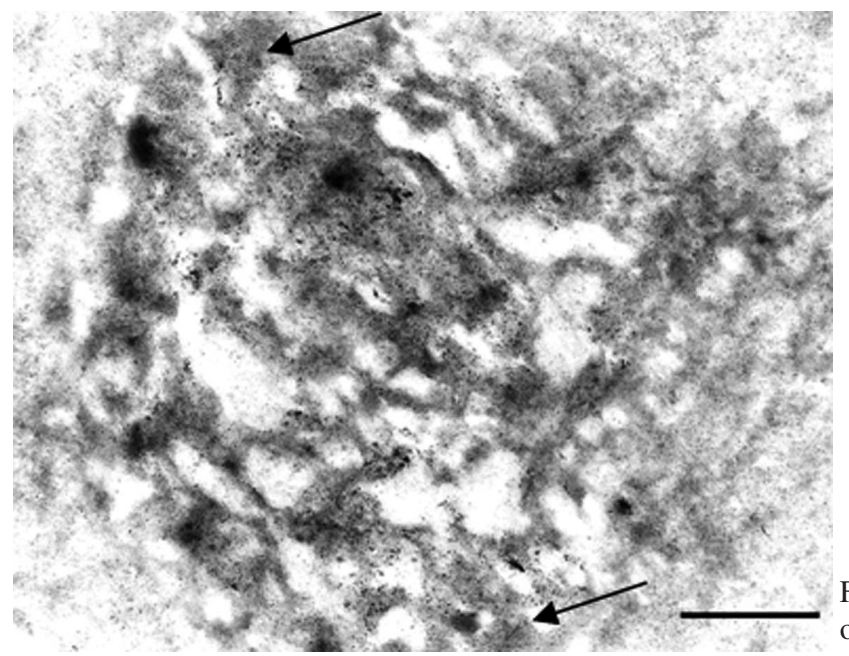

\section{DISCUSSION}

In this study, rabbits with poxvirus presented signs and symptoms, such as conjunctivitis, subcutaneous and perineal edema, and facial malformation conferring the animal a leonine aspect, as reported in the literature (Ferreira \& Ferreira; Corrêa \& Corrêa, 1992; Fenner et al.; Barbosa et al.; Bruno et al.).

It was observed that the periorbital region as well as testis of the studied animals had a gelatinous texture.

The mucoid nature of the lesion surface caused by poxvirus confers the name of myxomatosis to the disease (Fenner \& Ross, 1994).

Increase in volume of testis observed by us in some reproductive animals was also found by other authors (Ferreira \& Ferreira; Fountain et al.; Bruno et al.).

Some animals of our study showed neurological signs as nystagmus and motor incoordination. Studies indicated that animals may present paralysis as well (Fenner et al.).

No typical respiratory symptoms of the myxomatosis form described by Farsang et al. could be observed as well as pulmonary lesions verified by Bruno et al.

The two outbreaks occurred in the summer time when there is a bigger proliferation of transmitting insects as fleas, flies and mosquitoes, as analyzed by Corrêa \& Corrêa, Fenner et al. and Bruno et al. Mosquitoes as Aedes aegypti, Anopheles and Culex may act as virus reservoirs (Ferreira \& Ferreira). Airborne transmission had already been reported by Farsang et al.

A great number of typical poxvirus particles, measuring approximately $300 \times 240 \mathrm{~nm}$ was detected by negative contrast technique for transmission electron microscopy (rapid preparation) in all the analyzed samples.

These morphological features are in accordance with other myxomatosis studies (Padgett et al., 1964; Tektoff et al.; Strayer et al., 1983; Barbosa et al.; Luna).

The use of $2 \%$ ammonium molibdate allowed the ideal electronic contrast to viral identification by the negative staining technique. This stain is also indicated by OIE.

By means of the resin embedding technique, we observed oval poxvirus particles, measuring $270 \times 130 \mathrm{~nm}$,

Fig. 8. Ultrathin section of the fragments of skin. Intranuclear fibrillar or "digital" inclusions (arrow). Bar $=600 \mathrm{~nm}$. 


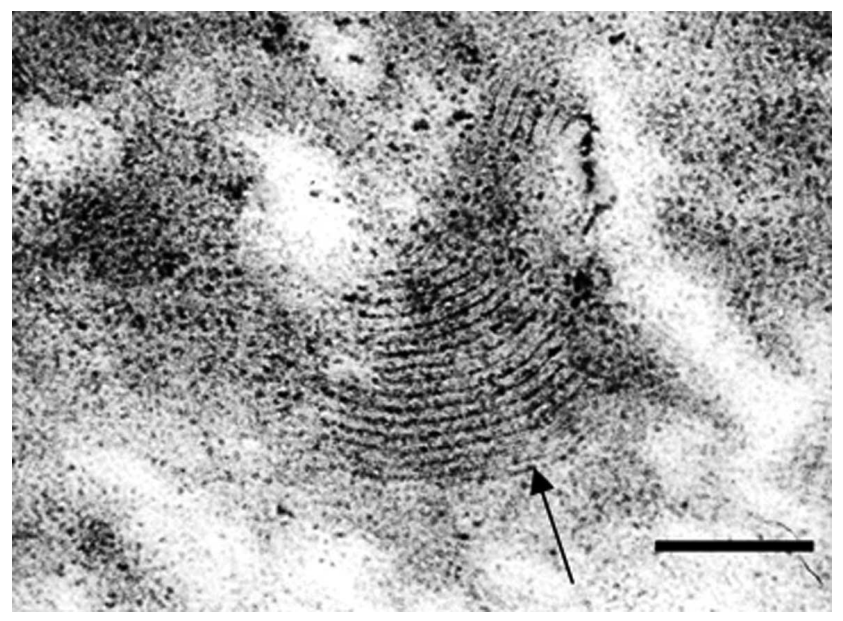

Fig. 9. Ultrathin section of the fragments of skin. Intranuclear fibrillar or "digital" inclusions showing a regular striation and arranged in groups (arrow). Bar: $170 \mathrm{~nm}$.

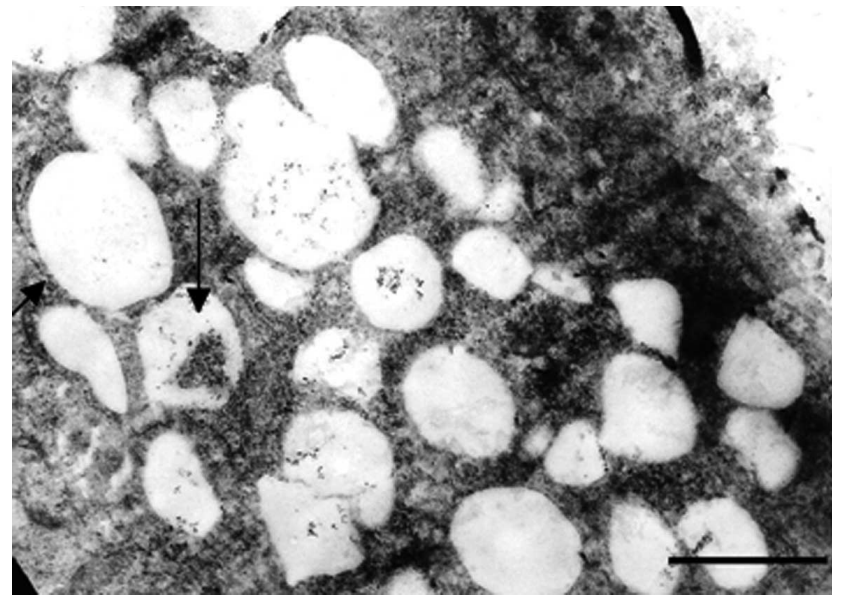

Fig. 10. Ultrathin section of the fragments of skin. Intracytoplasmic vacuoles, surrounded by membranes contained granular material in its interior (big arrow). Electron dense fibrils around some of the vacuoles (minor arrow). Bar $1200 \mathrm{~nm}$.

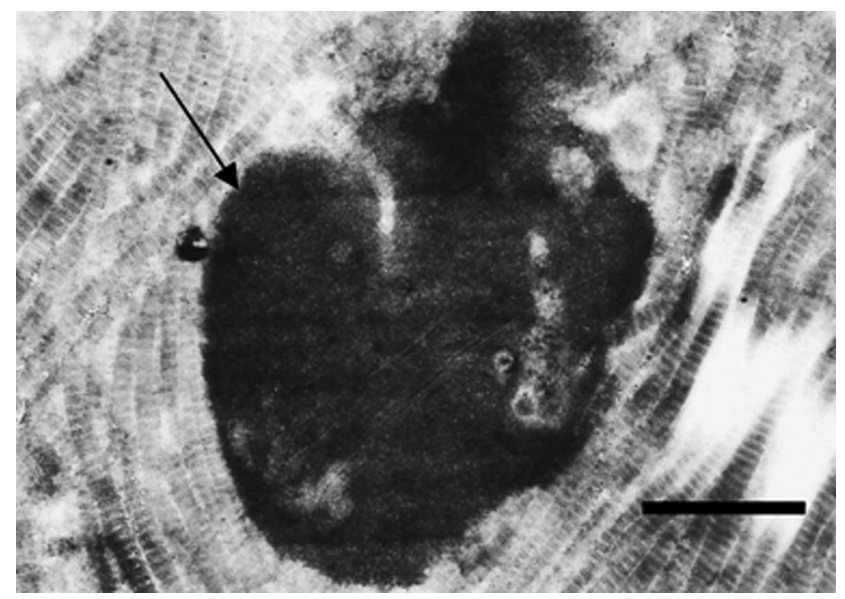

Fig. 11. Ultrathin section of the fragments of skin. Nuclei with densely condensed chromatin forming amorphous and electron dense inclusions bodies (arrow). Bar: $900 \mathrm{~nm}$. with a nucleus or biconcave (dumbbell-shaped) internal core. These aspects were also visualized by other authors (Tektoff et al.; Purcell \& Clarke; Ogier et al., 1974; Karstad et al., 1977; Bohn, 1980; Brooks et al., 1995; Saari et al.).

The presence of intracytoplasmatic inclusion bodies, surrounded by a membrane, containing complete and incomplete viral particles is in accordance with other investigations (Tektoff et al.; Purcell \& Clarke; Saari et al.). Additionally, we noted deformed nuclei with compacted dense chromatin forming electrodense and amorphous inclusions, intranuclear fibrilar or "digital" inclusions, showing periodical striation and disposed in groups among granular material as described in cases of swine variole and avianpox (Teppema \& Boer, 1975; Bersano et al., 2003; Catroxo et al., 2005; Melo et al., 2008).

In the immunocitochemistry technique, the intensive mark of poxvirus particles with colloidal gold allowed to confirm the poxvirus presence in the studied animals.

This technique was also used to mark particles of poxvirus in other cases of swine variole and avianpox (Bersano et al.; Catroxo et al., 2005; 2006; Melo et al., 2007; Catroxo et al., 2008).

The electron microscopy which is extensively used is advocated as the elective method to detect virus in fragments of skin lesions (Fenner et al.; Fenner \& Fantini; Robinson \& Kerr, 2001; OIE).

The employed techniques were crucial to diagnose the diseases in the mentioned outbreaks.

It is evident that precarious conditions with lack of medical and sanitary procedures contribute to myxomatosis introduction and distribution in several regions (Ghram et al.).

Thus, to avoid the disease outbreak, control and prevention measures were established in rabbitries, where hygienization was recommended into the breeding sheds, applying nylon insect doors and windows screen all over the facility, construction of pedilavium to access the shed, being mandatory the use of rubber boots for all the people who work or have free entrance to rabbitries and restricting the entrance of foreign people.

The results of the present study were valuable in the control and prevention of outbreaks in rabbitries as well to be careful when observing any suspicious symptom on these animals. 


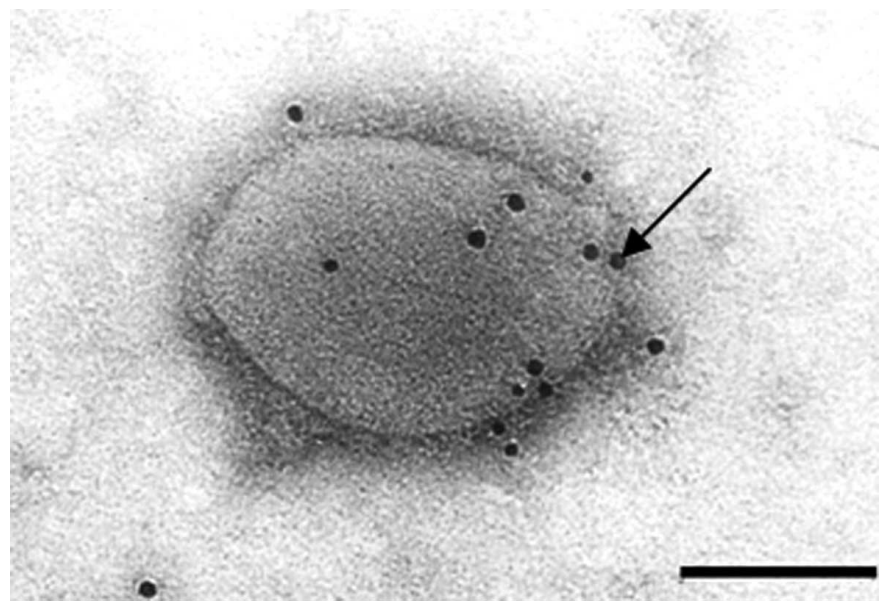

Fig. 12. Immunocytochemistry technique. Poxvirus marked by the particles of colloidal gold (arrow). Bar $=120 \mathrm{~nm}$.

CATROXO, M. H. B.; BERSANO, J. G.; MARTINS, A. M. C. P. F.; PETRELLA, S.; PORTUGAL, M.A. S. C. \& SOUZA, $O$. S. Estudio ultraestructural del poxvirus causal de mixomatosis en conejos, en São Paulo y Santa Catarina, Brasil. Int. J. Morphol., 27(2):543-552, 2009.

RESUMEN: La mixomatosis es una enfermedad contagiosa de distribución mundial, causada por poxvirus que infecta conejos domésticos y salvajes. En este estudio presentamos dos distintos surtos por mixomatosis que ocurrieron en producciones de conejos, una para fines comerciales de producción de carne y pieles y otra para el comercio de conejos domésticos. Las señales observadas fueron afecciones oculares, nasales, testiculares y, a veces, también distribuida por todo el cuerpo de los animales. Estas se caracterizaban por formación de nódulos que a la palpación tenían un aspecto gelatinoso o gomoso. En la microscopía electrónica de transmisión, por la técnica de contrastación negativa, se pudo observar en todas las muestras examinadas de piel y de costras, un gran número de partículas típicas de poxvirus, con envoltura y forma de ladrillo, mostrando disposición irregular de los túbulos sobre la membrana externa, midiendo 300 x $240 \mathrm{~nm}$ en el promedio. Cortes ultrafinos de fragmentos de piel y de costras revelaron la presencia de cuerpos de inclusión intracitoplasmáticas, envueltos por membrana y conteniendo partículas ovales, midiendo 270 x $130 \mathrm{~nm}$, conteniendo núcleo o centro interno bicóncavo (forma de mancuernas). Partículas inmaduras (vacías) envueltas por membrana fueron observadas. También fueron analizados cuerpos de inclusión intracitoplasmáticos, electrodensos, conteniendo partículas virales brotando del material denso y amorfo. Fueron observadas inclusiones intranucleares fibrilares o "digitales" mostrando una estriación periódica y disposición en grupos en medio del material granular. Los núcleos estaban deformados con cromatina densamente condensada formando cuerpos de inclusiones electrodensas y amorfas. En la técnica de imunocitoquímica la reacción antígeno-anticuerpo fue intensamente marcada por las partículas de oro coloidal realzando fuertemente las partículas virales.

PALABRAS ClaVE: Mixomatosis; Poxvirus; Conejo; Microscopía electrónica de transmisión.

\section{REFERENCES}

Arthur, C. P. \& Louzis, C. A review of myxomatosis among rabbits in France. Rev. Sci. Tech., 7:937-76, 1988.

Barbosa, G. A.; Rangel Filho, F. B.; Andrade, C. M.; Mazur, C.; Fontana, C. A. P.; Gripp, R. G.; Praxedes, C. S. \& Ribeiro, U. A. Mixomatose: infecção natural e experimental de uma amostra autóctone da área de influência da UFRRJ em coelhos domésticos (Oryctolagus cuniculus). Rev. Bras. Med. Vet., 18(6):256-9, 1996.

Beer, J. Doenças Infecciosas em Animais Domésticos. $1^{\text {a }}$. Ed. São Paulo, Roca, 1999. V.1. p. 380.

Bersano, J. G.; Catroxo, M. H. B.; Villalobos, E. M. C.; Leme, M. C. M.; Martins, A. M. C. R. P. F.; Peixoto, Z. M. P.; Portugal, M. A. S. C.; Monteiro, R. M.; Ogata, R. A. \& Curi, N. A. Varíola suína: Estudo sobre a ocorrência de surtos nos Estados de São Paulo e Tocantins, Brasil. Arq. Inst. Biol., 70(3):269-78, 2003.

Bohn, W. Electron microscopic immunoperoxidase studies on the accumulation of virus antigen in cells infected with Shope fibroma virus. J. Gen. Virol., 46:439-47, 1980.

Brenner, S. \& Horne, R. W. A negative staining method for high resolution electron microscopy of viruses. Biochim. Biophys. Acta, 34:103-10, 1959.

Brooks, M. A.; Ali, A. N.; Turner, P. C. \& Moyer, R. W. A rabbitpox virus serpin gene controls host range by inhibiting apoptosis in restrictive cells. J. Virol., 69(12):7688-98, 1995.

Bruno, S. F.; Lopes-Júnior, S. V. S.; Demarque, K. C.; Vieira, T. B. \& Tortelly, R. Achados clínicos e anatomopatológicos em um surto de mixomatose no Rio de Janeiro (relato de caso). Arq. Ciênc. Vet. Zool., 7:(1):85-8, 2004.

Calvete, C.; Estrada, R.; Villafuerte, R.; Osácar, J. J. \& Lucientes, J. Epidemiology of viral haemorrhagic disease and myxomatosis in a free-living population of wild rabbits. Vet. Rec., 150(25):776-82, 2002.

Cameron, C. M.; Barrett, J. W.; Liu, L.; Lucas, A. R. \& McFadden, G. Myxoma virus M141R expresses a viral CD200 (vOX-2) that is responsible for down-regulation of macrophage and T-cell activation in vivo. J. Virol., 79(10):6052-67, 2005. 
CATroxo, M. H. B.; BERSANO, J. G.; MARTINS, A. M. C. P. F.; PETRELLA, S.; PORTUGAL, M. A. S. C. \& SOUZA, O. S. Ultrastructural study of poxvirus causing myxomatosis in rabbits, in São Paulo, and Santa Catarina, Brazil. Int. J. Morphol., 27(2):543-552, 2009.

Cameron, C.; Hota-Mitchell, S.; Chen, L.; Barrett, J.; Cao, J. X.; Macaulay, C.; Willer, D.; Evans, D. \& McFadden, G. The complete DNA sequence of myxoma virus. Virol., 264(2):298-318, 1999.

Catroxo, M. H. B.; Pongiluppi, T.; Milanelo, L.; Godoy, S. N. \& Petrella, S. Identification of poxvirus under transmission electron microscopy during outbreak in wild birds. XXIII Congresso Brasileiro de Microbiologia, Santos, SP, 2005.

Catroxo, M. H. B.; Pongiluppi, T.; Milanelo, L.; Rebouças, M. M.; Jesus, T. H.; Cardoso, G. H. M. \& Petrella, S. Detection of poxvirus by transmission electron microscopy using negative staining (rapid preparation) and immunolabelling with colloidal gold particles techniques during outbreak in bay-winged cowbird (Gnorimopsar chopi). Virus Reviews \& Research, 11(suppl. 01):101, 2006.

Catroxo, M. H. B.; Melo, N. A.; Milanelo, L.; Rebouças, M. M.; Martins, A. M. C. R. P. F.\& Petrella, S. Detecção de poxvírus aviário em lesões cutâneas de bico-de-pimenta (Saltator atricollis). XXXII Congresso Anual da Sociedade de Zoológicos do Brasil, Sorocaba, SP, 2008.

Corrêa, W. M. \& Corrêa, C. N. M. Enfermedades infecciosas dos mamíferos domésticos. 2a . Ed. Rio de Janeiro, Médica e Científica, 1992.

Diven, D. G. An overview of poxviruses. J. Am. Acad. Dermatol., 44:1-16, 2001.

Doane, F. W. \& Anderson, M. Electron microscopy in diagnostic virology. In: A pratical guide and atlas. Cambridge, Cambridge University Press, 1987.

Farsang, A.; Makranszki, L.; Dobos-Kovács, M.; Virág, G.; Fabián K.; Barna, T.; Kulcsár, G.; Kucsera, L. \& Vetési, F. Occurrenceof atypical myxomatosis in Central Europe: clinical and virological examinations. Acta Vet. Hung., 51(4):493-501, 2003.

Fenner, F. Poxviruses. In: Fields, B. N.; Knife, D. M. \& Howley, P. M. (Eds.). Fields' Virology. Philadelphia, Lippincott-Raven, 1996. V.2. pp. 2673-702.

Fenner, F. Adventures with poxviruses of vertebrates. FEMS Microbiol. Rev., 24(2):123-33, 2000.

Fenner, F., Bachmann, P. A.; Gibbs, E. P. J.; Murphy, F. A.; Studdert, M. J. \& White, D. O. Virología Veterinaria. Zaragoza, Acribia, 1992.
Fenner, F. \& Fantini, B. Myxomatosis. In: The European rabbit. The history and biology of a succesful colonizer. Oxford, Ed. University Press, 1994. pp. 205-35.

Fenner, F. \& Hatclife, F. N. Myxomatosis. Cambridge. Ed. Cambridge University Press, 1965.

Fenner F. \& Ross J. Myxomatosis. In: The European Rabbit. The history and biology of a successful colonizer. Thompson, H. V. \& King, C. M. (Eds). Oxford, U. K., Oxford University Press, 1994. pp.205-40.

Ferreira, A. J. \& Ferreira, C. Doenças infecto-contagiosas dos animais domésticos. $4^{\mathrm{a}}$. Ed. Lisboa, Fundação Calouste Gulbenkian, 1990.

Fountain, S.; Holland, M. K.; Hinds, L. A.; Janssens, P. A. \& Kerr, P. J. Interstitial orchitis with impaired steroidogenesis and spermatogenesis in the testes of rabbits infected with an attenuated strain of myxoma virus. J. Reprod. Fertil., 110:161-9, 1997.

Ganière, J-P.; Gourreau, J-M.; Montabord, D.; Rive, M. \& Chantal, J. Myxomatosis of the depilated Angora rabbit. A preliminary study. Vet. Dermatol., 2(1):11-5, 2008.

Gelfi, J.; Chantal, J.; Phong, T. T.; Py, R. \& BoucrautBaralon, C. Development of an ELISA for detection of myxoma virus specific rabbit antibodies: test evaluation for diagnostic application on vaccinated and wild rabbit sera. J. Vet. Diagn. Invest., 11(3):240-45, 1999.

González-Santander, R. Técnicas de microscopia eletrónica en biología. Madrid, Ed. Aguilar, 1969. p. 666.

Ghram, A.; Benzarti, M.; Amira, A. \& Amara, A. Myxomatosis in Tunisia: seroepidemiological study in the Monastir region (Tunisia). Arch. Inst. Pasteur Tunis, 73(3-4):167-72, 1996.

Hayat, M. A. \& Miller, S. E. Negative Staining. New York, McGraw Hill Publ. Company, 1990. p.235.

Johnston, J. B.; Wang, G.; Barrett, J. W.; Nazarian, S. H.; Colwill, K.; Moran, M. \& McFadden, G. Myxoma virus M-75 protects infected cells from the stress of cell cycle arrest through its interaction with host cell cullin1. J. Virol., 79(16):10750-63, 2005.

Karstad, L.; Thorsen, J.; Davies, G. \& Kaminjolo, J. S. Poxvirus fibromas on African hares. J. Wildl. Dis., 13:245-7, 1977. 
CATROXO, M. H. B.; BERSANO, J. G.; MARTINS, A. M. C. P. F.; PETRELLA, S.; PORTUGAL, M. A. S. C. \& SOUZA, O. S. Ultrastructural study of poxvirus causing myxomatosis in rabbits, in São Paulo, and Santa Catarina, Brazil. Int. J. Morphol., 27(2):543-552, 2009.

Knutton, S. Electron microscopical methods in adhesion. Methods Enzymol., 253:145-58, 1995.

Luft, J. H. Improvements in an epoxy resin embedding methods. J. Biophys. Biochem. Cytol., 9:409-14, 1961.

Luna, R. M. L. First report of myxomatosis in Mexico. $J$. Wildl. Dis., 36(3):580-3, 2000.

Madeley, C. R. Electron microscopy and virus diagnosis. J. Clin. Pathol., 50:454-56, 1997.

Marcato, P. S. \& Simoni, P. Ultrastructural researches on rabbit myxomatosis. Lymphnodal lesions. Vet. Pathol., 14(4):361-7, 1977

Marlier, D.; Mainil, J.; Linde, A. \& Vindevogel, H. Infectious agents associated with rabbit pneumonia: isolation of amyxomatous myxoma virus strains. Vet. J., 159(2):171-8, 2000.

Melo, N. A.; Lopes; D.; Milanelo, L.; Rebouças; M. M.; Jesus, T. H.; Petrella, S. \& Catroxo, M. H. B. Presença de poxvírus em lesões cutâneas de pata do cardeal (Paroaria coronata). Biológico, 67(1):29, 2007.

Melo, N. A.; Milanelo, L.; Oliveira, A. C.; Rebouças, M. M.; Martins, A. M. C. R. P. F.; Petrela, S. \& Catroxo, M. H. B. Isolation of poxvírus in cutaneous lesions of the cowled-cardinal (Paroaria dominicana) by transmission electron microscopy techniques. In: XIV Congresso da Sociedade Brasileira de Biologia Celular, 2008, São Paulo, SP.

Merchant, J. C.; Kerr, P. J.; Simms, N. G.; Hood, G. M.; Pech, R. P. \& Robinson, A. J. Monitoring the spread of myxoma virus in rabbit Oryctolagus cuniculus populations on the southern tablelands of New South Wales, Australia. III. Release, persistence and rate of spread of an identifiable strain of myxoma virus. Epidemiol. Infect. 130(1):135-47, 2003.

OIE. Manual of Diagnostic Tests \& Vaccines for Terrestrial Animal. In: Lagomorpha. 6ª Ed. France, Paris, 2008. pp. 937-46.

Ogier, G.; Chardonnet, Y. \& Gazzolo, L. Role of lysosomes during infection with Shope fibroma virus of primary rabbit kidney tissue culture cells. J. Gen. Virol., 22:249$53,1974$.

Padgett, B. L; Wright, M. J.; Jayne, A. \& Walker, D. L. Electron microscopic structure of mixoma virus and some reactivable derivatives. J. Bacteriol., 87(2):454$60,1964$.

Purcell, D. A. \& Clarke, J. K. Some aspects of the morphogenesis of mixoma virus in vivo. Arch. Virol., 39(4):369-75, 1972.

Reinolds, E. S. The use of lead citrate at high $\mathrm{pH}$ as an electron-opaque stain in electron microscopy. J. Cell. Biol., 17:208-12, 1963.

Robinson, A. J. \& Kerr, P. J. Poxvirus Infections. In: Williams, E. S. \& Barker, I. K. (eds.). Infectious diseases of wild mammals. London, U.K., Manson Publishing Ltd., 2001. pp.179-201.

Ross, J.; Tittensor, A. M.; Fox, A. P. \& Sanders, M. F. Myxomatosis in farmland rabbit populations in England and Wales. Epidemiol.Infect., 103(2):333-57, 1989.

Saari, S. A. M.; Rudbäck, E.; Niskanen, M.; Syrjälä, P.; Nylund, M. \& Anttila, M. Contagious mucocutaneous dermatitis of the mountain hare (Lepus timidus): pathology and cause. J. Wildl. Dis., 41(4):775-82, 2005.

Shepherd, R. C. H.; Edmonds, J. W.; Nolan, I. F. \& Gocs, A. Myxomatosis in the Mallee region of Victoria, Australia. J. Hyg., 81(2):239-43, 1978.

Strayer, D. S.; Cabirac, G.; Sell, S. \& Leibowitz, J. L. Malignant rabbit fibroma virus: observations on the culture and histopathologic characteristics of a new virus-induced rabbit tumor. J. Natl. Cancer. Inst., 71(1):91-104, 1983.

Tektoff, J.; Gazzolo, L. \& Leftheriotis, E. Morphogènèse du virus de la myxomatose du lapin. Pathol. Biol., 19(23-24):1045-54, 1971.

Teppema, J. S. \& de Boer, G. F. Ultrastructural aspects of experimental swinepox with special reference to inclusion bodies. Arch. Virol., 49(2-3):151-63, 1975.

Upton, C.; Macen, J. L.; Wishart, D. S. \& McFadden, G. Myxoma virus and malignant rabbit fibroma virus encode a serpin-like protein important for virus virulence. Virology, 179(2):618-31, 1990.

Yuill, T. M. Mixomatosis y Fibromatosis. In: Davis. J. W.; Karstad. L. \& Trainer, D. Õ. Enfermedades Infecciosas de los Mamíferos Salvajes. Zaragoza, Ed. Acribia, 1972. 
CATroxo, M. H. B.; BERSANO, J. G.; MARTINS, A. M. C. P. F.; PETRELLA, S.; PORTUGAL, M. A. S. C. \& SOUZA, O. S. Ultrastructural study of poxvirus causing myxomatosis in rabbits, in São Paulo, and Santa Catarina, Brazil. Int. J. Morphol., 27(2):543-552, 2009.

Watson, M. L. Staining of tissue section for electron microscopy with heavy metals. J. Biophys. \& Biochem. Cytol., 4:475-8, 1958.

Zachertowska, A.; Brewer, D. \& Evans, D. H. Characterization of the major capsid proteins of myxoma virus particles using MALDI-TOF mass spectrometry. J. Virol. Methods., 132(1-2):1-12, 2006.
Correspondence to:

Prof. Dr. Marcia Catroxo

Electron Microscopy Laboratory

Research and Development Center in Animal Health

Biological Institute of São Paulo

Av. Conselheiro Rodrigues Alves, 1252

CEP 04014-002

Vila Mariana, São Paulo, SP

BRAZIL

E-mail: catroxo@biologico.sp.gov.br

Received: 10-02-2009

Accepted: 14-03-2009 